\title{
COVID-19: The use of fear to control the pandemic
}

\section{Dawei He${ }^{1}$ and Lara Parlatan²}

${ }^{1}$ Lawrence Park Collegiate Institute, Ontario, Canada

${ }^{2}$ Department of Pathology and Laboratory Medicine, Schulich School of Medicine and Dentistry, Western University, Ontario, Canada

KEYWORDS: COVID-19, behaviour, pandemic, health communication, health education

\section{THE NATURE AND PERCEPTION OF COVID-19}

The ongoing Coronavirus disease 2019 (COVID-19) pandemic has had a profound social and economic impact globally [1]. In retrospect, the widespread fear generated by the current pandemic is not so different from that of other pandemics not so long ago. Although fear is typically associated with misinformation and panic, which usually worsens the situation, the fear of COVID-19 can be used to prevent more infections if combined with accurate public health information.

There have been several large-scale pandemics in the 21st century, two of which are comparable to the COVID-19 pandemic: the 2003 SARS pandemic and the 2009 H1N1 pandemic. These pandemics were all caused by respiratory, droplet-transmitted viruses and elicited similar symptoms and behaviours from affected people [2-4].

Understandably, the topic of COVID-19 is filled with controversy: at the time of this writing, the recent discovery of the virus means that new research is constantly being generated, and their findings may contradict previous research. Furthermore, the drugs used to treat COVID-19, remdesivir and hydroxychloroquine, are still experimental, meaning they are at the centre of much scrutiny-and often controversy. More importantly, news about COVID-19 is highly politicized, with many media outlets heavily criticizing the United States (US) President Donald Trump's promotion of hydroxychloroquine and the efficacy of the drug itself [5-9], as well as turning the topic of quarantine from one of science to one of politics [10-12]. This overflow of contradicting information lends itself to uncertainty and controversy.

As of now, the fear of COVID-19 is widespread, and behavioural changes related to the pandemic have been reported across the globe. Surveys in China, the United Kingdom and the US on the current pandemic have all shown behavioural changes among a significant proportion of people, such as increased frequency of handwashing and avoidance of public places $[13,15]$. In a survey in mainland China, it was found that $56.5 \%$ of people "always [washed their] hands with soap" [13], and in a survey conducted in the US and UK, $92.6 \%$ and $86.0 \%$ of people respectively surveyed believed that handwashing "help[s] prevent catching an infection with the new coronavirus" [15]. There have also been other observed behaviours, with only $37.8 \%$ and $29.7 \%$ of people surveyed respectively in the US and UK believing that "consistently wearing a face mask is highly effective in protecting [them] from getting infected with the new coronavirus" [15], and some even exhibited an aversion to Chinese people and places [14-15].

\section{THE ORIGIN OF COVID-RELATED FEAR}

The COVID-19 panic likely stems from two factors: a perceived danger of the pathogen and a lack of consistent information presented to the public.

To determine how dangerous a pandemic is, its impact must be considered. One way that impact can be measured is by examining the number of infections and deaths due to the disease using the US as a case study. According to the Centers for Disease Control and Prevention (CDC), the 2003 SARS pandemic infected 8098 people worldwide, killing 774 people, while only 8 people "had laboratory evidence of SARSCoV infection" in the US [2]. The $2009 \mathrm{H} 1 \mathrm{~N} 1$ pandemic was estimated to have infected 60.8 million people with around 12500 deaths [3]. As of June 2020, COVID-19 has infected far fewer people at 5 million cases compared to H1N1, it has already killed more than 10 times as many people in the US [3,20], with infections and deaths still on the rise [20]. In addition, large-scale lockdowns were never applied during the SARS or H1N1 pandemics in the US, unlike the COVID-19 pandemic [21]. The greater case fatality rates caused by the 
current pandemic and the strength of government response may be contributing to the heightened perception of risk.

The information available now is anything but certain, or consistent, across publicly trusted sources. Take social distancing as an example: it seems that nobody can fully agree on the implementation of this important preventative measure. The World Health Organization website suggests a one-meter distance [20], yet the CDC mandates a two-meter distance between people [4], and there are studies that suggest even larger distances [24-25]. This lack of consistency is further exacerbated by social media panic and mainstream media controversies. A study by Oxford University Press concluded that social media panic travels faster than the COVID-19 pandemic [10]. This also affects mainstream media, with a prime example being the case of Donald Trump, who was criticized by mainstream media for promoting hydroxychloroquine to treat COVID-19. Many media articles have acted as if hydroxychloroquine was completely ineffective, with some even calling it a "false hope" [8-9], even though the drug is currently undergoing clinical trials and its effectiveness in treating COVID-19 has not yet been determined. With the lack of consistent information, the average person essentially regards COVID-19 as an unknown topic, and the fear of the unknown is a well-known fear with evolutionary origins [22]. The prevalence of this fear means that the average person, who does not have a thorough scientific background [26-29], will become confused and panic, or will stop believing in known public health agencies because of their political biases [30]. Indeed, a study on the Lancet stated that "uncertainty and perceived exaggeration were also associated with a reduced likelihood to implement the recommended behaviours" [19], which was also observed during the influenza pandemic in 2009-10 [31].

\section{THE USE OF FEAR TO CONTAIN THE COVID-19 PANDEMIC}

Paradoxically, the fear of COVID-19 can still be used for a good purpose. While maladaptive fear--the distrust of public organizations and hoarding supplies--is counterproductive for the effort to contain the pandemic, adaptive fear can be used to reduce the number of infections. In a 2010 study, Bish \& Michie (32) found associations between perceptions of susceptibility and the likelihood to carry out protective behaviours such as handwashing and wearing a mask during the 2008 H1N1 pandemic. [32] Therefore, it is likely that a greater perception or risk--and a greater fear of infection-will invoke more preventative measures from the public, and possibly slow down the rate of infection when guided by consistent information. A study supported this with authors stating that a lack of consistent information can lead to distrust in crisis response organizations and that consistently and accessibly distributed information can help people protect themselves and make informed choices [19].

An objective, consistent information campaign through various media platforms to remind people how to protect against COVID-19 could be an effective way to inform the public on the ongoing pandemic. In terms of spreading information, one might say such measures are already being implemented: there are many news articles covering the spread of the pandemic, popular platforms such as Google and YouTube contain easily accessible links to information on COVID-19, and many academic journals have their own COVID-19 subsection. Yet the links on websites are not easily found and only appear when viewing related content. Furthermore, these links often direct the user to general, often-politicized news, instead of academic journals or findings. Google Scholar can be a good source, and one way to enhance the spread of its information is putting short infographics on the front of the aforementioned popular websites. To ensure their accuracy, each infographic can be peer-reviewed, much like the process of publishing an academic essay. The "Thank You Coronavirus Helpers" series of sketches is a good example, being an interesting and unobtrusive way to link people to information on the pandemic, and it would be ideal if they linked to academic databases, such as Nature magazine's COVID-19 repository. Another approach can be promoting articles from websites that hire scientific writers to interpret findings from scientific articles or focus entirely on scientific content, at the forefront of Google results for searches concerning COVID-19. Furthermore, a continuous effort is needed in the distribution of information: for example, the Google main page no longer shows "Thank You Coronavirus Helpers" drawings or even a link to remind everyone of ongoing updates surrounding the pandemic. Although current information may not be consistent due to ongoing research, this does not preclude clear messaging and directions. With clear instructions for the public to follow, they can better understand the overall situation, lessening the number of infections via the enforcement of safety precautions.

The fear of COVID-19 may turn out to be a tool that can 
be used to slow down the infection rate, but it needs to be used carefully. Further studies should aim to optimize health communication and minimize distrust towards public health organizations. In this effort to inform the public about the disease, the mainstream media has the potential to play an instrumental role in preventing more infections.

\section{ACKNOWLEDGEMENTS}

I would like to thank the STEM Fellowship Journal for providing me the chance to participate in the STEMpowerment Viewpoint Competition, and my mentor, Lara Parlatan, who has helped greatly in improving my viewpoint.

\section{REFERENCES}

1. Nicola M, Alsafi Z, Sohrabi C, Kerwan A, Al-Jabir A, Iosifidis $C$, et al. The socio-economic implications of the coronavirus pandemic (COVID-19): A review [Internet]. 2020 [cited 20200ct3]. Available from: https://www.ncbi. nIm.nih.gov/pmc/articles/PMC7162753/

2. SARS [Internet]. Centers for Disease Control and Prevention. Centers for Disease Control and Prevention; 2005 [cited 2020]ul3]. Available from: https://www.cdc. gov/sars/about/faq.html

3. $2009 \mathrm{H} 1 \mathrm{~N} 1 \mathrm{Pandemic}$ (H1N1pdm09 virus) [Internet]. Centers for Disease Control and Prevention. Centers for Disease Control and Prevention; 2019 [cited 2020Jul3]. Available from: https://www.cdc.gov/flu/pandemicresources/2009-h1n1-pandemic.html

4. Social Distancing, Quarantine, and Isolation [Internet]. Centers for Disease Control and Prevention. Centers for Disease Control and Prevention; 2020 [cited 2020]ul3]. Available from: https://www.cdc.gov/coronavirus/2019ncov/prevent-getting-sick/social-distancing.html

5. Lovelace B, Breuninger K. Trump says he takes hydroxychloroquine to prevent coronavirus infection even though it's an unproven treatment [Internet]. CNBC. CNBC; 2020 [cited 2020]ul2]. Available from: https://www.cnbc.com/2020/05/18/trump-says-he-takeshydroxychloroquine-to-prevent-coronavirus-infection. html

6. Bennett G, Gregorian D. Trump chloroquine push came after talk with donor, source says [Internet]. NBCNews. com. NBCUniversal News Group; 2020 [cited 2020]ul2]. Available from: https://www.nbcnews.com/politics/ donald-trump/trump-chloroquine-push-came-after-talkdonor-source-says-n1190771

7. Bump P. Analysis | The rise and fall of Trump's obsession with hydroxychloroquine [Internet]. The Washington Post. WP Company; 2020 [cited 2020]ul2]. Available from: https://www.washingtonpost.com/politics/2020/04/24/ rise-fall-trumps-obsession-with-hydroxychloroquine/

8. Joshkelliott. Don't trust Trump's coronavirus 'cure,' says widow of man poisoned by chloroquine [Internet].
Global News. Global News; 2020 [cited 2020Jul2].

Available from: https://globalnews.ca/news/6723614/ coronavirus-chloroquine-donald-trump/

9. Elyse Samuels MK. Analysis | How false hope spread about hydroxychloroquine to treat covid-19 - and the consequences that followed [Internet]. The Washington Post. WP Company; 2020 [cited 2020Jul2]. Available from: https://www.washingtonpost.com/politics/2020/04/13/ how-false-hope-spread-about-hydroxychloroquine-itsconsequences/

10. Ellis EG. The Anti-Quarantine Protests Aren't About Covid-19 [Internet]. Wired. Conde Nast; 2020 [cited 2020Jul2]. Available from: https://www.wired.com/story/ anti-lockdown-protests-online/

11. Timberg C, Dwoskin E, Balingit M. Protests spread, fueled by economic woes and Internet subcultures [Internet]. The Washington Post. WP Company; 2020 [cited 2020Jul2]. Available from: https://www.washingtonpost. com/technology/2020/05/01/anti-stay-home-protests/

12. Spitzer RJ. Perspective | Why are people bringing guns to anti-quarantine protests? To be intimidating. [Internet]. The Washington Post. WP Company; 2020 [cited 2020Jul2]. Available from: https://www.washingtonpost. com/outlook/2020/04/27/why-are-people-bringing-gunsanti-quarantine-protests-be-intimidating/

13. Wang, Cuiyan, Riyu, Xiaoyang, Tan, Yilin, et al. Immediate Psychological Responses and Associated Factors during the Initial Stage of the 2019 Coronavirus Disease (COVID-19) Epidemic among the General Population in China [Internet]. 2020 [cited 2020Jun8]. Available from: https://www.mdpi.com/1660-4601/17/5/1729/htm

14. Depoux, Anneliese, Martin, Sam, Emilie, Preet, et al. pandemic of social media panic travels faster than the COVID-19 outbreak [Internet]. OUP Academic. Oxford University Press; 2020. Available from: https://academic. oup.com/jtm/article/27/3/taaa031/5775501

15. Geldsetzer P, Stanford University. Knowledge and Perceptions of COVID-19 Among the General Public in the United States and the United Kingdom: A Cross-sectional Online Survey [Internet]. 2020 [cited 2020Jun11]. Available from: https://www.acpjournals. org/doi/full/10.7326/M20-0912

16. Rubin GJ, Amlôt R, Page L, Wessely S. Public perceptions, anxiety, and behaviour change in relation to the swine flu outbreak: cross sectional telephone survey [Internet]. BMJ (Clinical research ed.). BMJ Publishing Group Ltd.; 2009 [cited 2020Jun15]. Available from: https://www. ncbi.nlm.nih.gov/pmc/articles/PMC2714687/

17. Reintjes R, Das E, Klemm C, Richardus JH, Keßler V, Ahmad A. "Pandemic Public Health Paradox": Time Series Analysis of the 2009/10 Influenza A / H1N1 Epidemiology, Media Attention, Risk Perception and Public Reactions in 5 European Countries [Internet]. PloS one. Public Library of Science; 2016 [cited 2020Jun15]. Available from: https://www.ncbi.nlm.nih.gov/pmc/ articles/PMC4794201/ 
18. McCauley M, Minsky S, Viswanath K. The H1N1 pandemic: media frames, stigmatization and coping [Internet]. BMC public health. BioMed Central; 2013 [cited 2020]ul3]. Available from: https://www.ncbi.nlm. nih.gov/pmc/articles/PMC3907032/

19. Betsch C, Wieler LH, Habersaat K. Monitoring behavioural insights related to COVID-19 [Internet]. The Lancet. The Lancet; 2020. Available from: https:// www.thelancet.com/journals/lancet/article/PIIS01406736(20)30729-7/fulltext

20. COVID-19 Map [Internet]. Johns Hopkins Coronavirus Resource Center. [cited 2020Jul3]. Available from: https://coronavirus.jhu.edu/map.html

21. Engle S, Stromme J, Zhou A. Staying at Home: Mobility Effects of COVID-19 [Internet]. SSRN. 2020 [cited 2020Jun11]. Available from: https://papers.ssrn.com/ sol3/papers.cfm?abstract_id=3565703

22. Carleton RN. Fear of the unknown: One fear to rule them all? [Internet]. Journal of Anxiety Disorders. Pergamon; 2016 [cited 2020Jul3]. Available from: https://www.sciencedirect.com/science/article/pii/ S0887618516300469

23. Advice for the public on COVID-19 [Internet]. World Health Organization. World Health Organization; 2020 [cited 2020]ul3]. Available from: https://www.who.int/ emergencies/diseases/novel-coronavirus-2019/advicefor-public

24. Javid B, Weekes MP, Matheson NJ. Covid-19: should the public wear face masks? [Internet]. The BM]. British Medical Journal Publishing Group; 2020 [cited 2020]ul3]. Available from: https://www.bmj.com/content/369/bmj. m1442

25. Painter M, Qiu T. Political Beliefs affect Compliance with COVID-19 Social Distancing Orders [Internet]. SSRN. 2020 [cited 2020]ul3]. Available from: https://papers.ssrn.com/ sol3/papers.cfm?abstract_id=3569098

26. Monmaney T. How Much Do Americans Know About Science? [Internet]. Smithsonian.com. Smithsonian Institution; 2013 [cited 2020]ul3]. Available from: https:// www.smithsonianmag.com/innovation/how-much-doamericans-know-about-science-27747364/

27. Public Knowledge About S\&T [Internet]. National Science Board. National Science Board; 2018 [cited 2020Jul3]. Available from: https://www.nsf.gov/statistics/2018/ nsb20181/report/sections/science-and-technologypublic-attitudes-and-understanding/public-knowledgeabout-s-t

28. Kennedy B, Hefferon M. What Americans Know About Science [Internet]. Pew Research Center Science \& Society. Pew Research Center; 2020 [cited 2020Jul3]. Available from: https://www.pewresearch.org/ science/2019/03/28/what-americans-know-aboutscience/

29. Funk C, Goo SK. What Americans know and don't know about science [Internet]. Pew Research Center Science \& Society. Pew Research Center; 2020 [cited
2020Jul3]. Available from: https://www.pewresearch.org/ science/2015/09/10/what-the-public-knows-and-doesnot-know-about-science/

30. Funk C. How Much the Public Knows about Science, and Why It Matters [Internet]. Scientific American Blog Network. Scientific American; 2019 [cited 2020]ul3]. Available from: https://blogs.scientificamerican.com/ observations/how-much-the-public-knows-aboutscience-and-why-it-matters/

31. Pakpour AH, Griffiths MD. The fear of COVID-19 and its role in preventive behaviors [Internet]. Concurrent Disorders Society. 2020 [cited 2020Jun15]. Available from: https://concurrentdisorders.ca/2020/04/03/thefear-of-covid-19-and-its-role-in-preventive-behaviors/

32. Bish A, Michie S. Demographic and attitudinal determinants of protective behaviours during a pandemic: A review [Internet]. Wiley Online Library. John Wiley \& Sons, Ltd; 2010 [cited 2020Jun15]. Available from: https://onlinelibrary.wiley.com/doi/ full/10.1348/135910710X485826 